\title{
MITIGASI SHARIA NON-COMPLIANCE RISK PENGEMBANGAN PRODUK KEUANGAN SYARIAH DI BANK PEMBIAYAAN RAKYAT SYARIAH \\ (Studi Kasus : PT. BPRS Mandiri Mitra Sukses)
}

\author{
Ahmad Hafid Afandi \\ Mahasiswa Progam Studi S1 Ekonomi Islam-Fakultas Ekonomi dan Bisnis Universitas Airlangga \\ Email: ahmad.hafid-13@feb.unair.ac.id \\ Noven Suprayogi Departemen Ekonomi Syariah-Fakultas Ekonomi Dan Bisnis Universitas \\ Airlangga \\ Email: noven.suprayogi@feb.unair.ac.id
}

\begin{abstract}
:
This research aims to analyze risk mitigation of Sharia Non-Compliance on the financial product development in the sharia financing bank. Risk mitigation of sharia noncompliance was including analization of product development proposal, analization of product study by director, analization of product study by commissioner, analization of study by sharia supervisor council (DPS). The method thatbused in this study was qualitative descriptive approach using study case on PT. Sharia Financing Bank (BPRS) Mandiri Mitra Sukses. The validation technic done using triangulation technic of source and technic. The analysis technic in this study was analysis technic of Miles and Huberman.

The result of this study according to the steps of product development risk mitigation of sharia non-compliance that presented the process of publishing product conducted by company management. Based on analysis that has been done by researcher, PT. BPRS Mandiri Mitra Sukses already capable to perform risk mitigation.
\end{abstract}

\section{Keywords: Process of Publishing Product, Risk Mitigation, Sharia Non-Compliance}

\section{PENDAHULUAN}

Undang - undang pasal 1 No. 21 tahun 2008, menyebutkan bank syariah menurut jenisnya terdiri atas bank umum syariah dan bank pembiayaan rakyat syariah (BPRS) dan pengertian BPRS adalah bank syariah yang dalam kegiatannya tidak memberikan jasa dalam lalu lintas pembayaran. Bank pembiayaan rakyat syariah (BPRS) dalam menjalankan fungsinya akan menghadapi risiko yang tidak dapat dipastikan waktu kejadiannya, sehingga BPRS perlu melakukan strategi menghadapi risiko yang akan terjadi kedepan.

Kejadian risiko dapat berdampak secara langsung maupun tidak langsung. ${ }^{1}$ Jurnal ini merupakan bagian dari skripsi Ahmad tanggal 14 Agustus 2017

Hartono (1995:62) menyatakan bahwa "Risiko adalah suatu ketidakpastian dimasa yang akan datang tentang kerugian". Terdapat tipe risiko yang dihadapi bank syariah diantaranya yaitu pada Pasal 5 ayat (1) PBI No.13/23/PBI/201 1 yaitu risiko kredit (risiko pembiayaan), risiko pasar, risiko likuiditas, risiko operasional, risiko hukum, risiko stratejik, risiko kepatuhan.

Terdapat permasalahan berkaitan dengan ketidakpatuhan lembaga kevangan syariah terhadap standar syariah di Indonesia yang dapat mengakibatkan terjadinya risiko hukum dan kepercayaan. Bisnis.com id Afandi NIM 041311433051 yang diuji pada 
Afandi, et al/Jurnal Ekonomi Syariah Teori dan Terapan Vol. 5 No. 11 November 2018: 921-936; MITIGASI SHARIA NON-COMPLIANCE RISK PENGEMBANGAN PRODUK KEUANGAN SYARIAH DI BANK PEMBIAYAAN RAKYAT SYARIAH (Studi Kasus : PT. BPRS Mandiri Mitra Sukses)

memberitakan pada tanggal 03 november 2015 jam 19:18 wib di Malang, Kepala Departemen Pemeriksaan Khusus dan Investigasi Perbankan Otoritas Jasa Keuangan (OJK) Tutty Kustiati memaparkan kegiatan operasional bank memiliki kompleksitas yang cukup tinggi yang memungkinkan oknum bank melakukan penyimpangan, baik administratif maupun pidana. "Untuk mengurangi potensi penyimpangan tersebut, bank wajib menjalankan operasionalnya dengan memperhatikan prinsip kehati-hatian, sehingga bukan saja bank akan terhindar dari masalah, tetapi yang jauh lebih penting adalah kepercayaan masyarakat yang menyimpan dananya di bank dapat tetap terpelihara," ujarnya dalam keterangan resminya, Selasa (3/11/2015). Maka penting untuk dilakukan pencegahan risiko ketidakpatuhan syariah di bank pembiayaan rakyat (BPRS). Pengelolaan bank pembiayaan rakyat syariah (BPRS) erat kaitannya dengan kegiatan pemberian pembiayaan yang di kenal sebagai aktivitas perkreditan, aktivitas ini memerlukan pengawalan, karena dikhawatirkan mendekati praktik riba. Maka penelitian ini fokus pada bank pembiayaan rakyat syariah (BPRS). Bank pembiayaan rakyat syariah (BPRS) yang diteliti adalah PT. BPRS Mandiri Mitra Sukses yang kantor pusatnya berada di daerah Kabupaten Gresik. Bank Pembiayaan Rakyat Syariah (BPRS) diteliti, karena memiliki produk yang mampu menarik minat nasasah, hal ini terlihat dari jumlah nasabah per bulan mei 2017 mencapai 16.000 nasabah sesuai dengan pernyataan Bapak Agus selaku direktur utama dan selama pengembangan produk perusahaan belum memiliki catatan penyimpangan kepatuhan syariah.

Berdasarkan laporan kinerja Pemerintah Kabupaten Gresik tahun 2015 jumlah usaha mikro kecil mengalami peningkatan. Hal ini merupakan peluang pasar yang besar bagi PT. BPRS Mandiri Mitra Sukses untuk meningkatkan kegiatan usaha perusahaan dengan menghadirkan produk unggulan yang sesuai kepatuhan syariah.

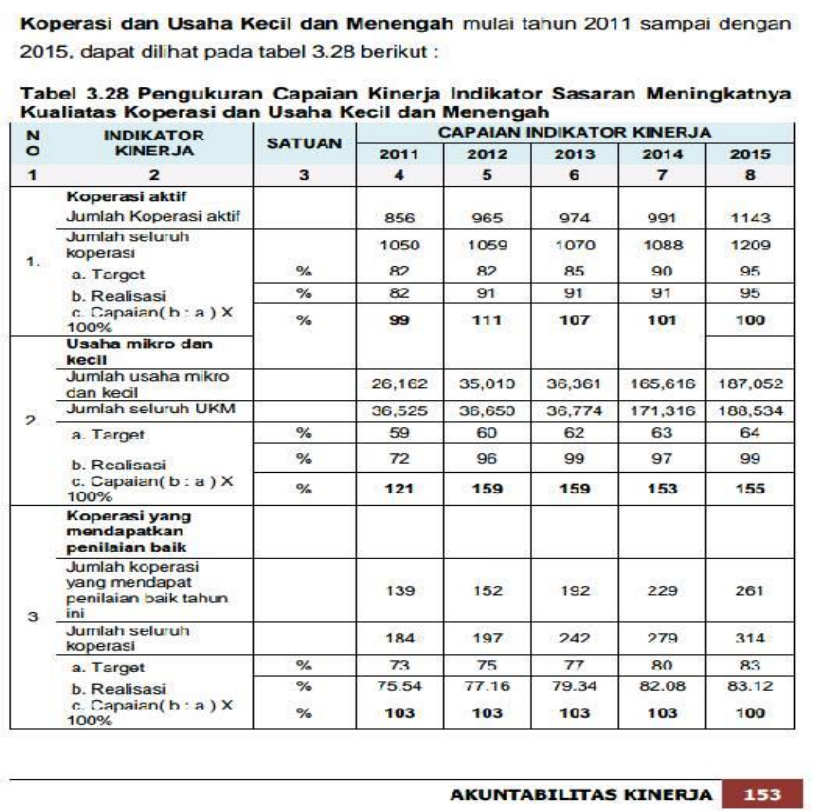

Sumber: Laporan Kinerja Pemerintah Kabupaten Gresik Tahun 2015

\section{Gambar 1.1}

\section{Jumlah Usaha Mikro Kecil di Kabupaten} Gresik

Unsur dalam perencanaan menghadapi risiko kedepan dapat dilakukan dengan langkah mitigasi risiko. Berdasarkan UU No.24 tahun 2007 mitigasi 
Afandi, et al/Jurnal Ekonomi Syariah Teori dan Terapan Vol. 5 No. 11 November 2018: 921-936; MITIGASI SHARIA NON-COMPLIANCE RISK PENGEMBANGAN PRODUK KEUANGAN SYARIAH DI BANK PEMBIAYAAN RAKYAT SYARIAH (Studi Kasus : PT. BPRS Mandiri Mitra Sukses)

adalah serangkaian upaya untuk mengurangi risiko bencana baik melalui pembangunan fisik maupun penyadaran dan peningkatan kemampuan menghadapi anacaman bencana. Langkah mitigasi risiko dapat dilakukan ketika lembaga keuangan syariah menciptakan produk dan produk tersebut terhindar dari risiko ketidakpatuhan syariah (sharia non-compliance).

Mengingat peluang pasar yang tinggi, maka PT. BPRS Mandiri Mitra Sukses akan membuat produk yang sesuai kebutuhan pasar dan sesuai kaidah syariah. Maka produk yang akan diterbitkan harus sesuai sesuai dengan ketentuan kaidah yang berlaku. Oleh karena itu, perlu dilakukan pencegahan risiko untuk meminimalisir dampak risiko yang akan dihadapi bank pembiayaan rakyat syariah (BPRS) dalam aspek shariah non-compliance pada produk.

Berdasarkan paparan latar belakang, rumusan masalah dalam penelitian ini adalah: bagaimana manajemen mitigasi sharia non compliance risk pada pengembangan produk keuangan bank pembiayaan rakyat syariah (BPRS) ?

Berdasarkan pada rumusan masalah, penelitian ini bertujuan untuk menganalisa proses manajemen mitigasi shariah non compliance risk pada pengembangan produk keuangan bank pembiayaan rakyat syariah (BPRS) di PT. BPRS Mandiri Mitra Sukses.

\section{LANDASAN TEORI}

Bank pembiayaan rakyat syariah (BPRS) merupakan bagian dari lembaga kevangan syariah yang berperan sebagai fasilitas penunjang kemaslahatan ekonomi masyarakat. Peran BPRS membantu sendi perekonomian masyarakat golongan bawah. Keberadaan BPRS adalah bagian dari bank syariah, namun dalam kegiatan operasionalnya memiliki perbedaan.

Berdasarkan UU No. 21 tahun 2008 tentang perbankan syariah bab IV pasal 21 kegiatan usaha bank pembiayaan rakyat syariah meliputi:

a. menghimpun dana dari masyarakat dalam bentuk:

1. simpanan berupa tabungan atau yang dipersamakan dengan itu berdasakan akad wadi'ah atau akad lain yang tidak bertentangan dengan prinsip syariah; dan

2. investasi berupa deposito atau tabungan atau bentuk lainnya yang dipersamakan dengan itu berdasarkan akad mudharabah atau akad lain yang tidak bertantangan dengan prinsip syariah

b. menyalurkan dana kepada masyarakat dalam bentuk: 
Afandi, et al/Jurnal Ekonomi Syariah Teori dan Terapan Vol. 5 No. 11 November 2018: 921-936; MITIGASI SHARIA NON-COMPLIANCE RISK PENGEMBANGAN PRODUK KEUANGAN SYARIAH DI BANK PEMBIAYAAN RAKYAT SYARIAH (Studi Kasus : PT. BPRS Mandiri Mitra Sukses)

1. pembiayaan bagi hasil berdasarkan akad mudharabah atau musyarakah

2. pembiayaan berdasarkan akad murabahah, salam, atau istishna

3. pembiayaan berdasarkan akad qardh

4. pembiayaan penyewaan barang bergerak atau tidak bergerak kepada nasabah berdasarkan akad ijarah atau sewa beli dalam bentuk ijarah muntahiya bittamlik; dan

5. pengambilalihan utang berdasarkan akad hawalah

c. menempatkan dana pada bank syariah lain dalam bentuk titpan berdasarkan akad wadi'ah atau investasi berdasarkan akad mudharabah dan/atau akad lain yang tidak bertentangan dengan prinsip syariah

d. memindahkan uang, baik untuk kepentingan sendiri maupun untuk kepentingan nasabah melalui rekening bank pembiayaan rakyat syariah yang ada di bank umum syariah, bank umum konvensional, dan UUS; dan

e. menyediakan produk atau melakukan kegiatan usaha bank syariah lainnya berdasarkan persetujuan Bank Indonesia.

Menurut Rivai dan Ismail (2013:56) risiko dalam ranah investasi didefinisikan

sebagai kemungkinan hasil yang diperoleh menyimpang dari yang diharapkan. Islam memandang bahwa risiko merupakan sebuah sunnatulloh dalam sebuah bisnis. Hal ini sesuai dengan firman Allah dalam QS. Luqman ayat 34:

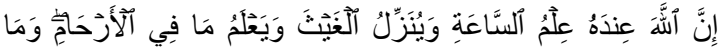

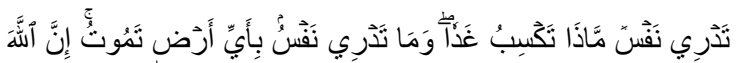

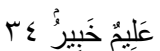
Inna al-Lāha 'indahu 'ilmu 'ssā'ati wayunazilu alghaytsa waya'lamu mā fī alarhāmi wamā tadrī nafsun mātsā taksibu ghadan wamaa tadrii nafsun bi-ayyi ardhin tamūtu inna al-Lāha 'allmun khabirun

"Sesungguhnya Allah, hanya pada sisi-Nya sajalah pengetahuan tentang Hari Kiamat; dan Dialah Yang menurunkan hujan, dan mengetahui apa yang ada dalam rahim. Dan tiada seorangpun yang dapat mengetahui (dengan pasti) apa yang akan diusahakannya besok. Dan tiada seorangpun yang dapat mengetahui di bumi mana dia akan mati. Sesungguhnya Allah Maha Mengetahui lagi Maha Mengenal". (Q.S Kementrian Agama Rl, 2014)

Menurut Antonio (2001) kepatuhan syariah adalah ketaatan bank syariah terhadap pemenuhan prinsip-prinsip syariah. Fungsi kepatuhan syariah adalah sebagai pengawasan yang bersifat preventif dan menjadi elemen penting dalam pengelolaan dan operasional bank syariah, pasar modal syariah, asuransi syariah, pegadaiaan syariah serta 
Afandi, et al/Jurnal Ekonomi Syariah Teori dan Terapan Vol. 5 No. 11 November 2018: 921-936; MITIGASI SHARIA NON-COMPLIANCE RISK PENGEMBANGAN PRODUK KEUANGAN SYARIAH DI BANK PEMBIAYAAN RAKYAT SYARIAH (Studi Kasus : PT. BPRS Mandiri Mitra Sukses)

lembaga keuangan syariah non bank (llham, 2009:477).

Menurut Lahsasna (2014) standar kepatuhan syariah dijadikan sebagai panduan oleh seluruh pegawai lembaga kevangan syariah, berikut standart yang digunakan:

1. Standar kepatuhan syariah yang tinggi akan memberikan reputasi yang baik, yang mana akan menarik fungsi bisnis dan nasabah

2.Menjamin penerapan hukum, peraturan, peraturan syariah, asas syariah, kebijakan internal, dan sesuai dengan pelatihan.

3. Ketaatan terhadap standart kepatuhan menjadi sebuah syarat dan kesempurnaan di lembaga keuangan syariah, hal ini berkaitan dengan persaingan antar setiap lembaga kevangan syariah

4. Mengidentifikasi dan menaksir potensi persoalan, memandu dan mengedukasi pegawai dalam hukum kepatuhan, peraturan, standart, dan melakukan pengawasan dan pelaporan.

Sharia non-compliance istilah lain dari ketidakpatuhan terhadap ketetapan syariah pada lembaga kevangan syariah. IFSB (2005) mendefinisikan Shari'ah noncompliance risk merupakan risiko yang ditimbulkan atas kegagalan menerapakan prinsip dan peraturan syariah yang sesuai dengan ketetapan hukum dalam operasional bank syariah.
Kegagalan penerapan prinsip syariah bagian yang harus dipertanggung jawabkan terutama terhadap Allah SWT dan reputasi bank syariah.

Berikut langkah mitigasi sharia noncompliance risk menurut Lahsasna (2014:102):

$$
\begin{gathered}
\text { Pre - Shariah compliance proses - risk } \\
\text { mitigation }
\end{gathered}
$$

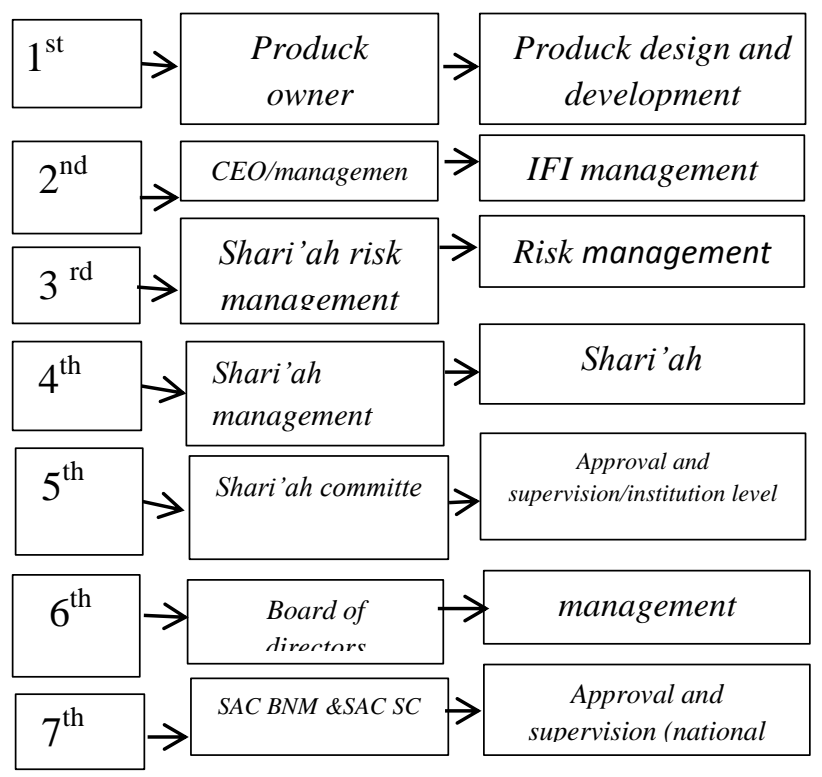

Post - shari'ah compliance process - risk identification and ratification

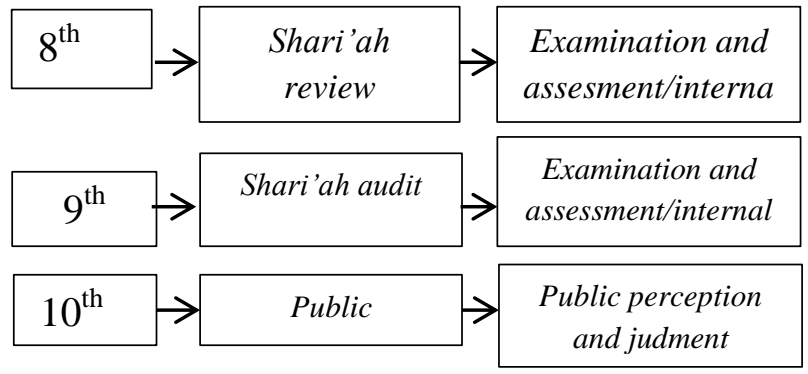

Sumber: Lahsasna, Ahcene. 2014. Shari'ah Non-Compliance Risk Management and Legal Documentation Islamic Finance. Singapore: Wiley Finance Series.

Gambar 1

Langkah dan Koridor Shari'ah NonCompliance di Bank Syariah 
Afandi, et al/Jurnal Ekonomi Syariah Teori dan Terapan Vol. 5 No. 11 November 2018: 921-936; MITIGASI SHARIA NON-COMPLIANCE RISK PENGEMBANGAN PRODUK KEUANGAN SYARIAH DI BANK PEMBIAYAAN RAKYAT SYARIAH (Studi Kasus : PT. BPRS Mandiri Mitra Sukses)

Produk Bank Pembiayaan Rakyat (BPRS) syariah menjadi tolak ukur keberlangsungan aktivitas keuangan dan operasional. Pendirian bank syariah semata untuk menciptakan kemaslahatan umat.

Produk perbankan syariah berkembang seiring dengan kebutuhan nasabah yang dinamis. Menurut Lewis dan Lativa (2007:215) "pengembangan inovasi produk kevangan syariah perbankan syariah harus dirancang instrumennya dan sesuai dengan standar internasional". "Inovasi produk yang dikembangkan harus disesuaikan dengan kualitas produk, kehandalan sumber daya manusia (SDM), fasilitas layanan dan teknologi serta perluasan jaringan pelayanan, berpedoman pada fatwa MUI yang telah ditetapkan oleh Dewan Syariah Nasional (DSN)" (Makhijani, 2010).

Ada beberapa penelitian sebelumnya yang terkait dengan penelitian ini, yaitu oleh Zurina Shafii, Supiah Salleh, dan Syahidawati $\mathrm{Hj}$ Shahwan dengan judul "Management of Shari'ah NonCompliance Audit Risk in the Islamic Financial Institution via the Development Of Shari'ah Compliance Audit Frame Work and Shari'ah Audit Progamme". Penelitian dipublikasikan pada bulan maret tahun 2010. Penelitian Zurina Shafii $\mathrm{dkk}$ memiliki persamaan dengan penelitian ini yaitu objek penelitianya pada risiko shari'a noncompliance pada lembaga keuangan syariah dan melihat shari'ah compliance untuk mempermudah dalam penelitian.

Namun, memiliki perbedaan tujuan penelitian, penelitian Zurina dkk fokus penelitian pada audit atas risiko yang dihadapi produk yang sudah ada. Kesimpulan penelitian ini yaitu risko ketidakpatuhan dapat di mitigasi dengan Shariah Compliance Audit.

Penelitian lain yang terkait dengan shari'ah non-compliance yaitu penelitiian yang dilakukan oleh Ahcene Lahsasna, dengan judul penelitian "Shari'ah noncompliance risk Management and Legal Documenttation in Islamic Finance". Penelitian ini dalam bentuk buku yang terbit pada tahun 2014. Penelitian Lahsasna memiliki persamaan dengan penelitian ini yaitu meneliti pada produk lembaga kevangan syariah dalam mengahadapi risiko shari'ah noncompliance dan memiliki perbedaan pada fokus penelitian, yaitu penelitian yang dilakukan Ahcene Lahsasna meneliti seluruh aspek dalam shariah noncompliance risk dan melakukan audit atas risiko yang dihadapi lembaga keuangan syariah. Kesimpulannya terdapat beberapa indikator dan klasifikasi dalam audit shari'ah non-compliance risk mulai dari risiko yang tinggi, medium, dan lemah.

Penelitian selanjutnya dilakukan oleh Budi Sukardi dengan judul "Kepatuhan Syariah (Shari'ah Compliance) dan Inovasi Produk Bank Syariah Di Indonesia". Penelitian Budi Sukardi di publikasikan oleh IAIN Surakarta. Persamaannya dalam 
Afandi, et al/Jurnal Ekonomi Syariah Teori dan Terapan Vol. 5 No. 11 November 2018: 921-936; MITIGASI SHARIA NON-COMPLIANCE RISK PENGEMBANGAN PRODUK KEUANGAN SYARIAH DI BANK PEMBIAYAAN RAKYAT SYARIAH (Studi Kasus : PT. BPRS Mandiri Mitra Sukses)

penelitian ini yaitu melakukan penelitian pada produk lembaga Bank Syariah dengan melihat aspek kepatuhan syariah. Namun, perbedaannya yaitu fokus penelitian yang berbeda, penelitian lebih fokus pada kepatuhan syariah dan tidak meneliti risiko Bank Syariah. Kesimpulannya inovasi harus unik dan sesuai prinsip kepatuhan syariah.

\section{METODE PENELITIAN}

Pendekatan yang digunakan dalam penelitian ini berdasarkan rumusan masalah yang melatarbelakangi penelitian ini adalah pendekatan kualitatif deskriptif. Menurut Yin (2003:4) penelitian kualitatif merupakan penelitian yang biasanya digunakan untuk meneliti persoalan - persoalan sosial, pendidikan, maupun komunikasi, penelitian ini melihat permasalahan dari berbagai disiplin ilmu, ranah, subyek permasalahan. Oleh karena itu, pendekatan kualitatif menekankan makna bukan generalisasi.

Jenis penelitian yang digunakan merupakan penelitian studi kasus. Yin (2003:5) mengatakan bahwa penelitian studi kasus adalah suatu metode yang secara khusus menyelidiki fenomena yang terdapat dalam konteks kehidupan nyata, yang dilakukan ketika batasan - batasan antara fenomena dan konteksnya belum jelas dan memanfaatkan berbagai sumber. Studi kasus yang menjadi obyek penelitian adalah di BPRS Mandiri Mitra Sukses, dengan tujuan mengetahui bagaimana mitigasi shari'ah noncompliance risk pada produk keuangan.

Berdasarkan sumbernya terdapat dua jenis sumber data yang dapat dijadikan sebagai bahan penelitian oleh peneliti, diantaranya adalah:

1. Data primer merupakan data yang dapat diperoleh dari sumber primer yaitu informan dari pihak BPRS Mandiri Mitra Sukses dengan melakukan wawancara secara langsung kepada pihak-pihak yang berkaitan dengan obyek penelitian. Pihak BPRS Mandiri Mitra Sukses yang menjadi informan sejumlah empat informan diantaranya adalah Direktur Umum, Direktur, Manajer Marketing and collection dan Dewan Pengawas Syariah (DPS).

2. Data sekunder merupakan data yang bersifat non-manusia sebagai data pendukung penelitian. Data yang diperoleh dari data pendukung berupa dokumen dan data pendukung lainnya seperti foto, jurnal, peraturan perbankan secara tertulis.

Unit analisis dalam penelitian ini adalah proses mitigasi risiko sharia noncompliance pada pengembangan produk keuangan di PT. BPRS Mandiri Mitra Sukses.

Penelitian ini menggunakan metode pengumpulan data sebagai berikut:

1. Wawancara 
Afandi, et al/Jurnal Ekonomi Syariah Teori dan Terapan Vol. 5 No. 11 November 2018: 921-936; MITIGASI SHARIA NON-COMPLIANCE RISK PENGEMBANGAN PRODUK KEUANGAN SYARIAH DI BANK PEMBIAYAAN RAKYAT SYARIAH (Studi Kasus : PT. BPRS Mandiri Mitra Sukses)

Menurut Yin (2003:108-109)

wawancara tipe open-ended

merupakan proses tanya jawab yang dilakukan kepada informan terkait dengan fenomena yang menjadi kasus penelitian agar diperoleh data yang dibutuhkan.

2. Dokumentasi

Menurut Yin (2003:104) "penggunaan dokumen paling penting adalah mendukung dan menambah bukti dari sumbersumber lain".

Validitas adalah derajat ketepatan yang terjadi antara data dengan daya yang dapat dilaporkan pada objek penelitian oleh peneliti. Data yang valid adalah data yang sama dengan data yang dilaporkan oleh peneliti berdasarkan keadaan yang benar-benar terjadi. Penelitian ini menggunakan teknik validasi triangulasi sumber dan teknik. Setelah dilakukan pengumpulan data penelitian, maka data tersebut dianalisis untuk mendapatkan kesimpulan. Data-data yang diperoleh dari proses wawancara, dan studi dokumen kemudian di analisis dan diolah berdasarkan landasan teori dan literatur yang digunakan dalam penelitian ini. Analisis data dilakukan agar hasil yang diperoleh dapat dibaca dengan mudah dan dipahami. Teknik analisis yang digunakan dalam penelitian ini menggunakan teori Miles dan Huberman (1992) dalam buku Yin, berikut tiga proses teknik analisis:

1. Data Reduction (Reduksi Data)

2. Data Display (Penyajian Data)
3. Conclusion Drawing/Verification

(Menarik Kesimpulan/Verifikasi)

\section{HASIL DAN PEMBAHASAN}

Pendirian PT BPRS Mandiri Mitra Sukses di inisiasi oleh beberapa investor yang banyak berkecimpung di berbagai bidang usaha, dan beberapa tokoh masyarakat yang aktif dalam pengembangan Masyarakat Ekonomi Syariah dan Majelis ekonomi Muhammadiyah (MEM) Jawa Timur yang terinspirasi untuk mengembangkan dan meningkatkan usaha mikro dengan sistem syariah. Tujuan pendirian BPRS ini untuk membebaskan usaha mikro masyarakat dari jeratan praktik penelolaan keuangan yang tidak sesuai syariah dan meningkatkan pertumbuhan perekonomian mikro.

BPRS ini didirikan dalam bentuk ketetapan hukum badan usaha perseroan terbatas (PT) dengan nama PT. BPR Syariah Mandiri Mitra Sukses yang disahkan Badan Hukum Perseroan dari Menteri Hukum dan Hak Asasi Manusia Republik Indonesia No: AHU17513.AH.01.01 tahun 2008.

Salah satu cara pengumpulan data yang digunakan dalam penelitian dengan menggunakan teknik wawancara terhadap informan yang sesuai dengan fokus penelitian ini. Terdapat empat informan yang dijadikan sumber data, informasi dari informan merupakan data 
Afandi, et al/Jurnal Ekonomi Syariah Teori dan Terapan Vol. 5 No. 11 November 2018: 921-936; MITIGASI SHARIA NON-COMPLIANCE RISK PENGEMBANGAN PRODUK KEUANGAN SYARIAH DI BANK PEMBIAYAAN RAKYAT SYARIAH (Studi Kasus : PT. BPRS Mandiri Mitra Sukses)

primer. Diantara informan tersebut yaitu pertama Bapak Agus Lukmanul Hidayat selaku Direktur Utama, kedua ketiga Bapak Samsun Arif selaku Direktur, ketiga Bapak Cahyo selaku manajer marketing dan collection, dan keempat Bapak Raditya Sukmana selaku DPS (Dewan Pengawas Syariah) PT BPRS Mandiri Mitra Sukses.

\section{Pembahasan}

Proses mitigasi risiko sharia noncompliance di PT. BPRS Mandiri Mitra Sukses melalui beberapa proses diantaranya adalah:

A. Kajian usulan penyusunan draft produk yang dikaji oleh manajer.

Penerbitan produk lahir atas dasar pencetusan ide pengusulan produk. Pihak manajemen perusahaan dalam pengusulan produk memberikan keterbukaan terhadap lini manajemen. Produk dapat diusulkan oleh manajer, direktur, direktur utama, dan intruksi komisaris. Usulan produk tersebut diajukan karena beberapa faktor yaitu faktor kebutuhan target pasar, hasil evaluasi dari produk yang sudah berjalan, dan keluhan dari nasabah. Kemampuan manajemen memanfaatkan setiap pelvang bisnis diperlukan untuk menciptakan produkproduk unggulan.

Proses mitigasi yang dilaksanakan di PT. BPRS Mandiri Mitra Sukses sejalan ketika proses penerbitan produk, dimulai pada saat ada pengusulan produk. Pada saat ada pengusulan produk, pihak manajer marketing akan membuat rancangan gambaran umum draft penyusunan produk dengan menentukan target pasar yang dibidik. Produk yang sesuai dengan target pasar dan kebutuhan nasabah akan mendatangkan keutungan bagi keuangan perusahaan. Sehingga pihak manajemen perusahaan mengupayakan dalam penerbitan produk sesuai dengan permintaan pasar.

Lahsasna, yang menyebutkan dalam penerbitan produk dimulai dengan pemilihan target pasar. Teori tersebut menyatakan "the development process in product compliance start by seleceting an aprroriate product for a niche market". Kesesuaian dengan teori ini karena melihat pentingnya penentuan target pasar, sehingga produk yang diterbitkan terarah.

Untuk menegetahui target pasar dan permintaan pasar PT. BPRS Mandiri Mitra Sukses melakukan survey dilapangan. Hasil dari survey nantinya akan menjadi bahan kajian dan pengambilan keputusan dalam penerbitan produk. Survey dikerjakan oleh manajer dan bawahannya seperti $A O$ (account oficcer). Terdapat beberapa aspek yang dilihat pada saat dilakukan survey, yaitu melihat peluang dan potensi bisnis kedepannya, apakah produk tersebut mampu mengatasi kebutuhan target pasar. Kemudian risiko yang akan akan dihadapi ketika penerbitan produk, seperti risiko pasar dan risiko kepatuhan 
Afandi, et al/Jurnal Ekonomi Syariah Teori dan Terapan Vol. 5 No. 11 November 2018: 921-936; MITIGASI SHARIA NON-COMPLIANCE RISK PENGEMBANGAN PRODUK KEUANGAN SYARIAH DI BANK PEMBIAYAAN RAKYAT SYARIAH (Studi Kasus : PT. BPRS Mandiri Mitra Sukses)

syariah. Apabila produk tersebut produk pembiayaan, maka akan melihat kemampuan nasabah mengembalikan pembiayaan yang diberikan. Selanjutnya aspek legalitas atas produk yang akad diterbitkan.

Berdasarkan hasil survey tersebut maka dirancang draft penyusunan produk oleh manajer marketing yang akan di diskusikan dengan direksi. Rancangan produk yang disusun isinya berupa jenis produk, karakteristik produk, jangka waktu pelaksanaan produk, syarat dan ketentuan yang berlaku, segmentasi pasar, rancangan akad yang digunakan, dan risiko yang kemungkinan dihadapi. Sistem penyusunan draft diawal yang dibuat manajer tidak ada kebijakan format penulisan yang tetap, hanya berupa catatan tidak resmi. Di perusahaan belum ada standar operasional prosedur (SOP) penyusunan usulan draft produk baru, sehingga tidak ada format penyusunannya.

Bagian yang menarik untuk dibahas yaitu berdasarkan hasil penelitian oleh peneliti PT.BPRS Mandiri Mitra Sukses belum memiliki standar operasional prosedur (SOP) usulan produk baru.

Terlepas dari belum adanya standar operasional prosedur (SOP), pihak manajemen perusahaan memiliki prinsip dalam pengusulan produk, apabila produk yang diusulkan memiliki risiko yang tinggi termasuk risiko ketidakpatuhan syariah (sharia non-compliance) maka produk tersebut tidak diterbitkan dahulu, meskipun dari segi aspek bisnis menguntungkan bagi perusahaan. Prinsip ini menjadi sebuah langkah mitigasi risiko ketidakpatuhan syariah yang menjadi pedoman perusahaan. Prinsip yang diterapkan sejalan dengan visi perusahaan yang menjadi menjadi bank yang sehat, tumbuh berkembang dan dipercaya oleh masyarakat serta menjadi bank yang rahmatan lil'alamin.

B. Melakukan kajian produk oleh tim direksi dalam penentuan instrumen produk yang lebih mendalam.

Hasil dari catatan draft penyusunan produk yang dibuat manajer akan didiskusikan bersama komite direksi. Pihak yang terlibat dalam kajian komite direksi yaitu direktur utama, direktur, dan manajer.

Terdapat beberapa aspek yang diperhatikan dalam pengkajian draft produk di forum komite direksi. Kajian yang dilakukan secara detail mulai dari penetuan akad produk tersebut. Penggunaan akad ini penting ditentukan sejak awal. Salah satu ciri khas dari lembaga keuangan syariah yaitu akad yang digunakan. Akad sebagai bentuk pengikatan diawal transaksi. Selanjutnya Komite direksi melihat aspek bisnis untuk menjaga ksatabilan kegiatan usaha perusahaan, dari produk yang akan diterbitkan apakah mampu mendatangkan keuntungan bagi perusahaan dan mampu bertahan dipasaran berapa lama. Selain penentuan penggunaan akad dan aspek bisnis direksi akan mengkaji risiko yang kemungkinan 
Afandi, et al/Jurnal Ekonomi Syariah Teori dan Terapan Vol. 5 No. 11 November 2018: 921-936; MITIGASI SHARIA NON-COMPLIANCE RISK PENGEMBANGAN PRODUK KEUANGAN SYARIAH DI BANK PEMBIAYAAN RAKYAT SYARIAH (Studi Kasus : PT. BPRS Mandiri Mitra Sukses)

terjadi. Sebagai bentuk meminimalisir risiko akan melihat kemampuan sumber daya insani (pegawai) dalam mengoperasikan produk yang diterbitkan. Kajian analisis risiko dilakukan secara detail, karena apabila dalam kajiannya kurang tepat akan berdampak pada keberlangsungan produk tersebut dan operasi keuangan perusahaan. Kajian risiko yang berkaitan dengan risiko ketidakpatuhan syariah diperhatikan oleh perusahaan. Kepatuhan terhadap pedoman syariah yang harus dipenuhi sebagai lembaga keuangan syariah. Pemenuhan kaidah syariah pada produk akan selalu meminta masukan dewan pengawas syariah (DPS) selaku kepanjanganan tangan dewan syariah nasional majelis ulama' Indonesia (DSNMUI).

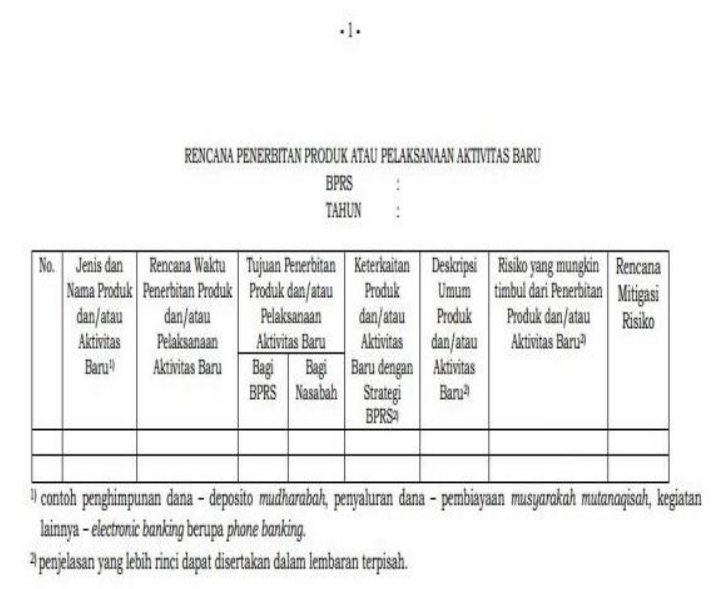

Sumber: Salinan Surat Edaran Otoritas Jasa Keuangan Nomor 37/SEOJK.03/2015 Tentang Produk dan Aktivitas Bank Pembiayaan Rakyat Syariah Tahun 2015

\section{Gambar 2}

\section{Rencana Penerbitan Produk atau \\ Pelaksanaan Aktivitas Baru}

Selain mengkaji dan finalisasi penyusunan draft produk di forum rapat komite, direksi akan membuat SOP yang berisi petunjuk pelaksanaan dan petunjuk teknis untuk produk baru bukan produk turunan. Hasil final dari rapat direksi maka langkah selanjutnya akan di ajukan ke komisaris, dewan pengawas syariah (DPS), dan pengajuan otoritas jasa kevangan (OJK). Produk yang diajukan ke otoritas jasa keuangan (OJK) merupakan produk yang masuk dalam kategori produk baru bukan produk turunan dari produk yang sudah berjalan. Apabila produk tersebut produk turunan dari produk yang sudah berjalan, maka pihak direksi hanya membuat surat edaran (SE) bukan standar operasional prosedur (SOP).

Dewan direksi memiliki wewenang mengevaluasi produk yang telah diterbitkan. Hasil evaluasi akan menjadi rujukan apakah produk tersebut tetap layak dioperasikan atau perlu adanya penambahan atau pengurangan karakteristik produk. Produk yang perlu tambahan atau pengurangan akan didiskusikan kembali untuk diterbitkan kembali dengan mengeluarkan surat edaran (SE). Proses evaluasi merupakan salah satu langkah untuk memitigasi terjadinya risiko ketidakpatuhan syariah pada produk.

Proses evaluasi produk menurut Lahsasna (2014:109) bahwa fungsi 
Afandi, et al/Jurnal Ekonomi Syariah Teori dan Terapan Vol. 5 No. 11 November 2018: 921-936; MITIGASI SHARIA NON-COMPLIANCE RISK PENGEMBANGAN PRODUK KEUANGAN SYARIAH DI BANK PEMBIAYAAN RAKYAT SYARIAH (Studi Kasus : PT. BPRS Mandiri Mitra Sukses)

pengendalian manajemen risiko syariah sebagai bagian mengacu pada identifikasi, penilaian, pemantauan, dan pengendalian melalui pendekatan sistematis untuk mengurangi kemungkinan kejadian ketidakpatuhan.

Proses evaluasi produk dilakukan PT. BPRS Mandiri Mitra Sukses sebagai bentuk pemantauan. Jangka waktu evaluasi biasa dilakukan enam bulan sekali, tetapi evaluasi juga bisa dilakukan sewaktuwaktu sesuai kebutuhan dan berdasarkan adanya keluhan dari nasabah.

C. melakukan kajian produk melalui rapat komite bersama komisaris. Pihak direksi mengadakan rapat komite bersama komisaris yang akan membahas produk yang diusulkan.

Komisaris akan memberikan pandaganannya yang berkaitan dengan aspek bisnis jangka panjang, sehingga dari produk yang diusulkan apakah mampu bersaing dengan produk lembaga keuangan lainnya. Dalam memberikan pandangannya pihak komisaris akan memperhatikan ulasan direksi, bagaimana urgensitas dari penerbitan tersebut. Pihak komisaris mengharapkan dari produk yang diterbitkan mendatangkan keuntungan bagi perusahaan dan tidak memiliki risiko terutama risiko kepatuhan. Karena keuntungan yang didapat perusahaan akan berdampak pada bagi hasil yang diperoleh pemegang saham. Hasil dari rapat komite dengan komisaris selanjutnya kan diusulkan ke pihak DPS.
D. melakukan kajian produk oleh dewan pengawas syariah (DPS) dalam pemenuhan kaidah syariah.

Ketika ada usulan produk yang diajukan pihak dewan pengawas syariah (DPS) akan melihat dan mengkaji dokumen yang diajukan manajemen perusahaan. Pihak yang menghubungi DPS selama ini adalah direktur utama. Pihak direktur utama akan menghubungi DPS secara langsung dan mengirimkan dokumen pengusulan penerbitan produk.

Pihak dewan pengawas syariah (DPS) akan melihat beberapa aspek pada saat ada pengsulan produk terutama aspek pemenuhan kaidah syariah yang berlaku sesuai dengan DSN-MUI. Diantara aspek yang dilihat dewan pengawas syariah (DPS) yaitu jenis produk yang di usulkan, kesesuaian fatwa DSN-MUI yang digunakan pada produk tersebut, konsep akad yang digunakan, formulir aplikasi produk, obyek transaksi dan tujuan penggunaan, penetapan biaya administrasi, penetapan potongan dan perlakuan terhadap agunan sebagai aspek legalitas syariah.

Sesuai dengan surat edaran OJK No. 37/SEOJK.03/2015 pada romawi VII poin tujuh, terdapat beberapa aspek yang akan dikaji oleh dewan pengawas syariah (DPS) dan dijadikan sebagai opini yaitu,

a. Produk dan/atau Aktivitas baru mendasarkan pada fatwa Dewan 
Afandi, et al/Jurnal Ekonomi Syariah Teori dan Terapan Vol. 5 No. 11 November 2018: 921-936; MITIGASI SHARIA NON-COMPLIANCE RISK PENGEMBANGAN PRODUK KEUANGAN SYARIAH DI BANK PEMBIAYAAN RAKYAT SYARIAH (Studi Kasus : PT. BPRS Mandiri Mitra Sukses)

Syariah Nasional - Majelis Ulama Indonesia (DSN - MUI);

b. Kesesuaian Produk dan/atau Aktivitas baru dengan fatwa DSN-MUI paling sedikit mencakup:

1) Akad yang digunakan dan pemenuhan unsur-unsur dalam akad yang digunakan;

2) Obyek transaksi dan tujuan penggunaan;

3) Kesesuaian penetapan bonus/nisbah bagi hasil/margin/ujrah/fee dengan akad yang digunakan, termasuk dalam hal diperlukan kaji ulang (review) terhadap nisbah bagi hasil/margin/ujrah (untuk produk penyaluran dana);

4) Penetapan biaya administrasi; dan

5) Penetapan hadiah, denda/sanksi dan/atau ganti rugi, potongan, pelunasan dipercepat, dan perlakuan terhadap agunan, apabila ada.

c. Standar operasional prosedur Produk dan/atau Aktivitas baru terkait dengan pemenuhan Prinsip Syariah; dan

d. Hasil kaji ulang terhadap konsep akad/perjanjian/formulir aplikasi Produk dan/atau Aktivitas baru terkait dengan pemenuhan Prinsip Syariah,

Dewan pengawas syariah memiliki langkah untuk memastikan bahwa produk yang diusulkan sudah sesuai dengan kaidah syariah. Dewan pengawas syariah akan meminta masukan ke dewan pengawas syariah lain sebagai rekomendasi opini. Langkah ini sebagai bentuk memperkuat opini yang akan menjadi rujukan keputusan penerbitan produk. Selain itu, dewan pengawas syariah akan mencocokan dengan ketetapan fatwa DSN-MUI. Apabila produk tersebut sudah sesuai maka produk tersebut layak diterbitkan dan tidak menimbulkan risiko ketidakpatuhan syariah.

Hasil dari analisis dewan pengawas syariah (DPS) akan dijadikan opini produk tersebut yang selanjutkan akan diajukan ke pihak otoritas jasa keuangan. Opini yang dikeluarkan dewan pengawas syariah (DPS), sebagai bentuk kekuatan kepatuhan syariah dan akan menjadi pertimbangan otoritas jasa keuangan (OJK). Format opini yang disampaikan dewan pengawas syariah seperti gambar dibawah ini. 
Afandi, et al/Jurnal Ekonomi Syariah Teori dan Terapan Vol. 5 No. 11 November 2018: 921-936; MITIGASI SHARIA NON-COMPLIANCE RISK PENGEMBANGAN PRODUK KEUANGAN SYARIAH DI BANK PEMBIAYAAN RAKYAT SYARIAH (Studi Kasus : PT. BPRS Mandiri Mitra Sukses)

OPINI SYARIAH DEWAN PENGAWAS SYARIAH (DPS)

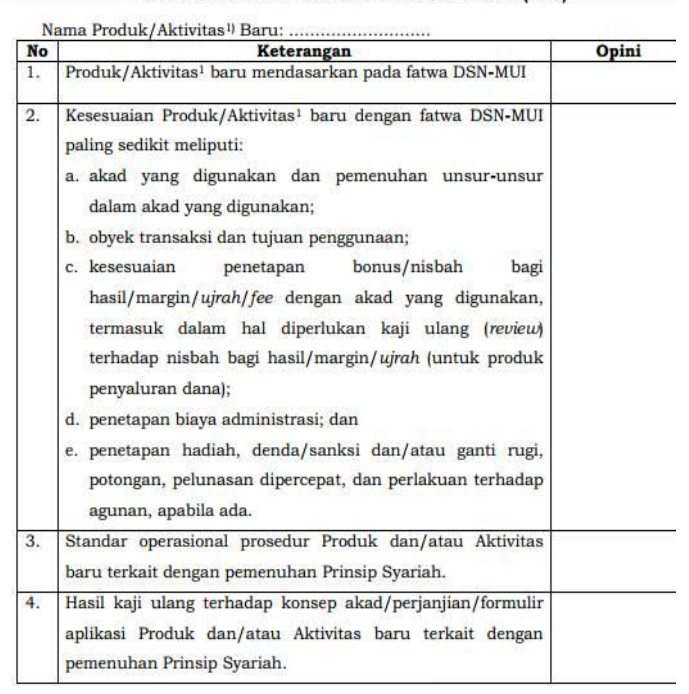

Kesimpulan :

(Tempat), (Tanggal, Bulan, Tahun)

(Dewan Pengawas Syariah) (Dewan Pengawas Syariah)

Sumber: Salinan Surat Edaran Otoritas Jasa

Keuangan Nomor 37/SEOJK.03/2015

Tentang Produk dan Aktivitas Bank

Pembiayaan Rakyat Syariah Tahun 2015

\section{Gambar 3}

\section{Opini Syariah Dewan Pengawas Syariah}

Produk yang diajukan ke OJK merupakan produk yang sudah melalui proses kajian dan perhitungan mitigasi risiko. Terdapat beberapa dokumen yang perlu dilampirkan dalam pengajuan produk yang sesuai dengan panduan penerbitan produk dari otoritas jasa keuangan syariah (OJK).

Pihak OJK selaku regulator lembaga keuangan akan memeriksa usulan penerbitan produk. Hasil pemeriksaan otoritas jasa keuangan (OJK) akan memberitahukan kepada perusahaan atas usulan produk tersebut. Hasil dari pemberitahuan otoritas jasa keuangan (OJK) akan menjadi kekuatan legalitas produk tersebut. Produk yang diajukan ke OJK adalah produk yang bukan turunan produk yang sudah berjalan.

\section{SIMPULAN}

Berdasarkan hasil penelitian yang dilakukan dapat disimpulkan bahwa PT. Bank Pembiayaan Rakyat Syariah (BPRS) melakukan proses mitigasi risiko sharia noncompliance dalam pengembangan produk sebagai berikut:

1. Proses mitigasi risiko sharia noncompliance di awali dengan kajian usulan penyusunan draft produk yang dikaji oleh manajer. Pada saat ada usulan penyusunan produk manajer akan membuat rancangan draft produk dengan menentukan target pasar yang dibidik. Untuk menegetahui target pasar dan permintaan pasar manajer dengan dibantu bawahannya seperti (account officer) melakukan survey dilapangan. Terdapat beberapa aspek yang dilihat pada saat dilakukan survey, yaitu melihat peluang dan potensi bisnis kedepannya, risiko yang kemungkinan terjadi. Berdasarkan hasil survey tersebut maka dirancang draft penyusunan produk oleh manajer marketing yang akan di diskusikan dengan direksi. Rancangan 
Afandi, et al/Jurnal Ekonomi Syariah Teori dan Terapan Vol. 5 No. 11 November 2018: 921-936; MITIGASI SHARIA NON-COMPLIANCE RISK PENGEMBANGAN PRODUK KEUANGAN SYARIAH DI BANK PEMBIAYAAN RAKYAT SYARIAH (Studi Kasus : PT. BPRS Mandiri Mitra Sukses)

produk yang disusun isinya berupa jenis produk, karakteristik produk, jangka waktu pelaksanaan produk, syarat dan ketentuan yang berlaku, segmentasi pasar, rancangan akad yang digunakan, dan risiko yang kemungkinan dihadapi.

2. Kajian produk oleh tim direksi dalam penentuan instrumen produk yang detail. Berdasarkan hasil survey tersebut maka dirancang draft penyusunan produk oleh manajer marketing yang akan di diskusikan dengan direksi. Kajian yang dilakukan secara detail mulai dari penetuan akad produk tersebut. Penggunaan akad ini penting ditentukan sejak awal, sebagai pengikat transaksi. Kajian selamjutnya aspek bisnis dan legalitas produk tersebut. Penyusunan produk disesuaikan dengan pedoman yang telah ditetapkan otoritas jasa keuangan (OJK) dan merujuk pada fatwa DSN-MUI, hal ini sebagai bentuk mitigasi risiko ketidakpatuhan. Hasil kajian yang dilakukan direksi akan menghasilkan standar operasional prosedur (SOP) atau surat edaran (SE).

3. Kajian produk melalui rapat komite bersama komisaris

Pihak direksi mengadakan rapat komite bersama komisaris yang akan membahas produk yang diusulkan. Komisaris akan memberikan pandaganannya yang berkaitan dengan aspek bisnis jangka panjang. Sehingga dari produk yang diusulkan apakah mampu bersaing dengan produk lembaga keuangan lainnya. Dalam memberikan pandangannya pihak komisaris akan memperhatikan ulasan direksi, bagaimana urgensitas dari penerbitan tersebut.

4. Kajian produk oleh dewan pengawas syariah (DPS) dalam pemenuhan kaidah syariah. Ketika ada usulan produk yang diajukan pihak dewan pengawas syariah (DPS) akan melihat dan mengkaji dokumen yang diajukan manajemen perusahaan. Pihak dewan pengawas syariah (DPS) akan melihat beberapa aspek pada saat ada pengsulan produk terutama aspek pemenuhan kaidah syariah yang berlaku sesuai dengan DSN-MUI. Diantara aspek yang dilihat dewan pengawas syariah (DPS) yaitu jenis produk yang di usulkan, kesesuaian fatwa DSN-MUI yang digunakan pada produk tersebut, konsep akad yang digunakan, formulir aplikasi produk, obyek transaksi dan tujuan penggunaan, penetapan biaya administrasi, penetapan potongan dan perlakuan terhadap agunan sebagai aspek legalitas syariah.

Saran yang direkomendasikan setelah melakukan penelitian ini adalah sebagai berikut:

1. Bagi Institusi Bank Pembiayaan Rakyat Syariah

Proses mitigasi risiko Sharia NonCompliance perlu diterapkan 
Afandi, et al/Jurnal Ekonomi Syariah Teori dan Terapan Vol. 5 No. 11 November 2018: 921-936; MITIGASI SHARIA NON-COMPLIANCE RISK PENGEMBANGAN PRODUK KEUANGAN SYARIAH DI BANK PEMBIAYAAN RAKYAT SYARIAH (Studi Kasus : PT. BPRS Mandiri Mitra Sukses)

secara tersistematis bagi setiap mengingat pentingnya analisis lembaga keuangan syariah, Seharusnya proses mitigasi lakukan mitigasi risiko Sharia Nontidak berdasarkan kebiasaan yang telah dijalankan manajemen perusahaan. Perlu adanya standar operasional prosedur (SOP) penyusunan produk.

Compliance. Kepatuhan terhadap pedoman kaidah syariah merupakan ciri khas yang dimiliki lembaga keuangan syariah. Penelitian selanjutnya baiknya dapat lebih mendalami instrumen

2. Bagi Peneliti Selanjutnya penyusunan produk dan model Mitigasi risiko Sharia NonCompliance merupakan sesuatu hal menarik di teliti, karena penyusunan produk yang secara kaidah syariah tidak dapat diragukan lagi. 
Afandi, et al/Jurnal Ekonomi Syariah Teori dan Terapan Vol. 5 No. 11 November 2018: 921-936; MITIGASI SHARIA NON-COMPLIANCE RISK PENGEMBANGAN PRODUK KEUANGAN SYARIAH DI BANK PEMBIAYAAN RAKYAT SYARIAH (Studi Kasus : PT. BPRS Mandiri Mitra Sukses) Daftar Refrensi

Antonio, Muhammad Syafi'i.2001. Bank Syariah: Dari Teori ke Praktek.Jakarta: Gema Insani Press

Bank Indonesia.2011. Peraturan Bank Indonesia No. 13/23/PBI/2011 tentang Penerapan Manajemen Risiko Bagi Bank Umum Syariah Dan Unit Usaha Syariah. Jakarta

Hartono, Sri Redjeki. 1995. Hukum Asuransi dan Perusahaan Asuransi.Jakarta: Sinar Grafika, hlm.62

IFSB, Islamic Financial Service Board.2005. Guiding Principles of Risk Management for Institution (Other Than Insurance Institution), offering only Islamic Financial Service, hlm. 26

Illami, Haniah.2009. Pertanggungjawaban Dewan Pengurus Syariah Sebagai Otoritas Pengawas Kepatauhan Syariah Bagi Bank Syariah, Jurnal Mimbar Hukum, Volume 21 Nomor 3, Oktober 2009, hlm..477

Kementrian Agama RI. 2014. Mushaf AtTammam Al-Qur'an dan Terjemahnya. Solo : PT.Tiga Serangkai Pustaka Mandiri

Lahsasna, Ahcene.2014.Shari'ah NonCompliance Risk Management and Legal Documentation in Islamic Finance.Singapore: Wiley Finance Series.

Lewis, Mervyn K dan Lativa M.Algaoud. 2007. Perbankan Syariah: Prinsip, Praktik dan Prospek. Jakarta: PT. Serambi IImu Semesta. halm 215

Otoritas Jasa Keuangan.2015. Salinan Surat Edaran Otoritas Jasa Keuangan Nomor 37/Seojk.03/2015 Tentang Produk dan Aktivitas Bank Pembiayaan Rakyat Syariah. Jakarta

Yin. Robert K. 2003. Studi Kasus: Desain dan Metode, Terjemahan. Jakarta: PT Raja Grafindo Persada

Rivai dan Ismail.2013.Islamic Risk Management For Islamic Bank: Jakarta

http://www.bi.go.id/peraturan/arsipperatr an/perbankan2003/pbi-5-8-2003.pdf.

Diakses pada tanggal 09/02/2017

http://finansial.bisnis.com/read/20151103/ 90/488554/peyelewengan-pemberian-

kredit-dominasi-kasus-perbankan.

Dimuat pada 03 november 2015 jam 19:18 wib di Malang, diakses pada tanggal 20 april 2017 jam 06.29 WIB. 